\title{
Interleukin-7 Is a Growth Factor for Sézary Lymphoma Cells
}

\author{
Ali Dalloul, * Liliane Laroche," Martine Bagot," M. Djavad Mossalayi, * Christine Fourcade, * Dean J. Thacker," \\ Donna E. Hogge," Helène Merle-Béral, * Patrice Debré, * and Christian Schmitt* \\ *Groupe d'Immuno-Hématologie Moléculaire, Laboratoire d'Immunologie, CNRS URA 625, CHU Pitié-Salpêtrière, 75013 Paris; \\ ${ }^{\ddagger}$ Unité de Dermatologie, Hôpital Avicenne, Bobigny 93009, France; ${ }^{\S}$ Service de Dermatologie, Hôpital Henri Mondor, Créteil 94010 , \\ France; and "Terry Fox Laboratory, British Columbia Cancer Agency, Vancouver V5Z IL3, Canada
}

\begin{abstract}
Sézary syndrome is a cutaneous $\mathbf{T}$ cell lymphoma characterized by infiltration of the skin by $\mathrm{CD4}^{+}$cells. These cells generally respond poorly to mitogens and $T$ cell activators. We have studied the action of IL1 to ILA, IL6, and IL7 on the proliferation of Sézary cells from 12 patients. With the exception of IL2 and IL7, the cytokines studied had no proliferative effect on these cells. Whereas IL2 had only a low proliferative capacity (twoto threefold increase) on peripheral blood mononuclear cells, recombinant IL7 constantly induced a very significant (3-40fold increase ) proliferative response, and was used successfully to generate cell lines in three out of eight cases. Growth of Sézary cell lines was shown to be strictly dependent on IL7, and after 2-5 wk of culture presented a switch to a homogeneous phenotype $\mathrm{CD}^{+} 4^{+} 8^{-} 7^{-}$(except for one line that remained $\mathrm{CD}^{+}$), with a typical morphology of Sézary cells. Their tumoral origin was demonstrated by the expression of the same $T$ cell receptor- $\beta$ gene rearrangement as the patients' $T$ cells. Importantly, cultured normal epidermal keratinocyte supernatants could support the growth of our Sézary lines. Furthermore, the proliferative activity contained in these supernatants was completely blocked by a monoclonal anti-IL7 antibody. These results suggest that IL7 may, therefore, represent an important cytokine in the physiopathology of cutaneous $T$ cell lymphoma. (J. Clin. Invest. 1992. 90:1054-1060.) Key words: cytokines $\bullet$ cutaneous $T$ cell lymphoma $\bullet$ proliferation • cell lines - surface markers
\end{abstract}

\section{Introduction}

Sézary syndrome is a lymphoproliferative disorder characterized by infiltration of the skin by malignant T cells (1). It is associated with erythroderma, generalized lymphadenopathy, and circulating neoplastic cells containing convoluted cerebriform nuclei $(2,3)$. Sézary cells are of mature $T$ helper phenotype (4-6), although lack of CD7 antigen expression is a general feature of these cells $(7,8)$. In contrast to adult $T$ cell leukemia/lymphoma, an aggressive disorder that has been shown to be associated with infection by HTLV-I, Sézary syndrome is a relatively indolent disorder of unknown ethiology, those cells respond poorly to $\mathrm{T}$ cell mitogens, to $\mathrm{CD} 2$ and $\mathrm{CD} 3$

Address correspondence to Dr. Christian Schmitt, Ph.D., Groupe d'Immuno-Hématologie Moléculaire, CHU Pitié-Salpêtrière, 91 Bd de l'Hôpital, Porte 510, 75013 Paris, France.

Received for publication 10 February 1992.

J. Clin. Invest.

(C) The American Society for Clinical Investigation, Inc.

$0021-9738 / 92 / 09 / 1054 / 07 \$ 2.00$

Volume 90, September 1992, 1054-1060 pathways of activation, and to IL2 (9-11). This low responsiveness explains why attempts to grow these cells are generally unsuccessful, and could be attributed to requirements for a growth factor distinct from IL2 (12-14).

We have studied the action of cytokines relevant to $T$ cell proliferation: IL1 to IL4, IL6, and IL7 on PBMC from 12 patients. We found that among these molecules, only IL2 and IL7 had significant growth effect. However, whereas IL2 had a limited and inconstant effect, IL7 induced a very significant growth (3-40-fold increase) of these cells. IL7, originally described as a mouse pre-B cell growth factor, has been shown to induce human peripheral blood $T$ cell proliferation $(15,16)$. Interestingly, IL7 is produced by mesenchymal cells, but not by T cells (16). Responsiveness to IL7 gave a selective advantage to tumoral cells, since we were able to enrich PBL from four patients in Sézary cells within 3 wk of culture. This led to the establishment of three IL7-dependent cell lines with a homogenous $\mathrm{CD} 3^{+} 4^{+} 8^{-} 7^{-}$phenotype (except for one line which remained $\mathrm{CD}^{+}$), typical Sézary morphology, and the same $\mathrm{T}$ cell receptor (TCR) $\beta$ gene rearrangement as the patients' blood T cells. Sézary/mycosis fungoides syndrome is generally associated with hyperkeratosis. In addition, it has been shown that tumoral cells proliferate in the skin but not in blood (17, 18). We also demonstrate here that supernatants from various epithelial cells could induce Sézary cell growth caused by IL7 production by these epithelial cells. Thus, IL7 production by epidermal keratinocytes may be an essential factor for the maintenance of malignant $\mathrm{T}$ cell cycling and tumor progression in Sézary syndrome/mycosis fungoides.

\section{Methods}

Patients. We studied 12 patients with their informed consent, 9 males and 3 females, (onset of disease: $38-79 \mathrm{yr}$ age/mean: $59 \pm 10.5$, evolution at the time of diagnosis: $0-12 \mathrm{yr}$, mean $3.5 \pm 4 \mathrm{yr}$ ), followed in dermatology departments of the Avicenne and Henri Mondor hospitals. All patients had generalized erythroderma with various associated signs, including hyperkeratosis, severe itching, and exfoliation. Patients classified according to the mycosis fungoides cooperative group were all of stage IV. Leukocytosis varied from 8,500 to $85,000 / \mathrm{mm}^{3}$, with $\mathrm{CD}^{+}$lymphocyte counts from 44 to $93 \%$ of the cells. One patient (BOS) had a severe eosinophilia $\left(40,000 / \mathrm{mm}^{3}\right)$.

$m A b$ and immunofluorescence analysis. A panel of FITC-conjugated or phycoerythrin-conjugated (PE) mAb used in this study included anti-CD4 (T4), anti-CD7 (I21), anti-CD8 (T8), anti-CD2 (T11), anti-CD3 (T3), anti-CD25 (IL2R1), anti-CD14 (My4), and anti-CD19 (B4), all from Coulter clone (Margency, France), antiCD56 (leu 19) (Becton Dickinson, Pont-de-Claix, France), anti-CD71 (OKT9) (Ortho Pharmaceutical, Raritan, NJ), and anti-HLA-DR (D1.12). Mononuclear cells $\left(10^{6} / 0.1 \mathrm{ml}\right)$ were incubated $20 \mathrm{~min}$ at $4^{\circ} \mathrm{C}$ in the dark with FITC and PE-mAb for two-color immunofluorescence staining. Controls consisted of cells stained with isotypematched mouse immunoglobulins conjugated to FITC or PE. Scatter 
gated PBMC were analyzed using a FACStar $^{\circledR}$ cytometer (Becton Dickinson).

mAb anti-IL7 was a kind gift from Dr. A. Namen (Immunex, Seattle, WA).

Cytokines. $\mathrm{rILl} \beta(50 \mathrm{U} / \mathrm{ml}), \mathrm{rIL}-2(50 \mathrm{U} / \mathrm{ml}), \mathrm{rIL} 3(50 \mathrm{U} / \mathrm{ml})$, and rIL4 ( $100 \mathrm{U} / \mathrm{ml}$ ), all from Sandoz (Geneva, Switzerland), rIL6 ( $10 \mathrm{U} / \mathrm{ml}$, kind gift of C. Damais, Paris, France), rIL7 ( $10 \mathrm{ng} / \mathrm{ml}$, Tebu, LePerray en Yvelines, France). Human IL7 was also used as supernatants of a murine bone marrow-derived stromal cell line (M210B4) infected with a retrovirus (JZEN-TK.Neo) containing the human IL7 gene (M210B4-hIL7). Mock supernatants used as control were obtained from M210B4 infected with the original retroviral vector (D. Thacker).

Proliferation assay. Cells $10^{5} / 0.1 \mathrm{ml}$ were incubated in triplicate in 96-well round bottom plates with PHA-M (10 $\mu \mathrm{g} / \mathrm{ml}$ from Sigma Chemical Co., St. Louis, MO), or cytokines in RPMI 1640 10\% FCS (Seromed, Berlin, Germany). Cultures were pulsed overnight with 1 $\mu \mathrm{Ci} /$ well $\left[{ }^{3} \mathrm{H}\right]$ thymidine (CEA Gif/Yvette, France), and radioactivity was measured on days 3 and 6 of culture by liquid scintillation counting (Beckman, Gagny, France).

$T$ cell culture. PBMC from patients were cultured at $5 \times 10^{5} / \mathrm{ml}$ with 20\% M210B4-hIL7 supernatant (IL7-sup) in RPMI 1640 supplemented with $10 \%$ FCS. Some cultures were initiated with autologous serum in place of FCS during the first 2 wk of culture. Medium was changed twice a week, and cultures were split when cell concentration reached $2 \times 10^{6}$ cells $/ \mathrm{ml}$. Cells were cultured thereafter by half medium changed every 2-3 d, and maintained at $0.5-1 \times 10^{6} / \mathrm{ml}$. To show IL-7 dependency, some cultures were switched to IL-7-free medium by replacing IL-7-sup with $20 \%$ M210B4-Neo supernatant (Mock-sup)

Epithelial cell culture. Epithelial cells were collected from children undergoing corrective surgery of the abdomen or ears, as described (19, 20 ), slightly modified. Briefly, skin was cut into pieces of $1 \mathrm{~cm}^{2}$ and floated on $0.25 \%$ trypsin for $1 \mathrm{~h}$ at $37^{\circ} \mathrm{C}$. Cell suspension was removed and trypsin was inactivated with FCS. Cells were then washed in RPMI 1640 with $100 \mu \mathrm{g} / \mathrm{ml}$ DNAse and cultured in flasks at 4,000 cells $/ \mathrm{cm}^{2}$, and viability, assessed by trypan blue exclusion, was always $>90 \%$. Culture medium used was DME (Flow Laboratories, Irvine, Scotland) containing $10 \%$ FCS, $100 \mathrm{mM}$ pyruvate, $200 \mathrm{mM}$ glutamin, $4.5 \mathrm{~g} /$ liter glucose, $3.7 \mathrm{~g} / 1 \mathrm{NaHCO}_{3}, 100 \mu \mathrm{g} / \mathrm{ml}$ penicillin, $100 \mu \mathrm{g} / \mathrm{ml}$ streptomycin, $2.5 \mu \mathrm{g} / \mathrm{ml}$ Amphotericin $\mathrm{B}, 0.4 \mu \mathrm{g} / \mathrm{ml}$ hydrocortisone, $20 \mathrm{ng} / \mathrm{ml}$ EGF, and $10^{-10} \mathrm{M}$ cholera toxin (all from Sigma). Medium was changed every 3-4 d and cells were grown to confluence within 4-6 wk.
Keratinocyte nature was assessed by positive immunostaining with anticytokeratin, but not by antivimentin antibodies, as previously described (20). For IL7 production, confluent cultures were washed with culture medium and incubated for $48 \mathrm{~h}$ with $2 \mathrm{ml}$ medium per $25 \mathrm{~cm}^{2}$ flask.

Southern blot analysis. DNA was extracted and purified from Sézary PBMC and from established cell lines from three patients (BEL, CHA, RIC), according to standard procedure (21). For TCR- $\beta$ gene rearrangement, $10 \mu \mathrm{g}$ of genomic DNA were digested with BamHI, EcoRI, and HindIII restriction enzymes and separated by electrophoresis in $0.6 \%$ agarose gel. Separated DNA fragments were then transferred onto nylon membrane (Hybond N; Amersham, Les Ulis, France), and hybridized with ${ }^{32} \mathrm{P}$-labeled probe specific for $\mathrm{C} \beta 1$ and $\mathrm{C} \beta 2$ TCR- $\beta$ constant regions (22). Autoradiography was performed by exposure on Kodak X-AR5 film with intensifying screens.

$I L-7$ bioassay. IL-7 bioactivity was measured using a thymocyte proliferation assay based on the direct mitogenic activity of both murine and human IL7 on murine thymocytes (23). Briefly, 3-wk-old BALB/c thymocytes were cultured at $10^{6}$ cells per well in $0.2 \mathrm{ml}$ of RPMI 1640 medium supplemented with $10 \% \mathrm{FCS}, 5 \times 10^{-5} \mathrm{M} 2$-mercaptoethanol, $200 \mu \mathrm{g} / \mathrm{ml}$ glutamine, and containing serial dilutions of the supernatant to be assayed or known concentrations of purified recombinant human IL7. After $3 \mathrm{~d}$, cultures were pulsed with $1 \mu \mathrm{Ci}$ per well $\left[{ }^{3} \mathrm{H}\right] \mathrm{TdR}$ and harvested $6 \mathrm{~h}$ later for counting. In these conditions, all the mitogenic activity contained in the supernatants could be blocked by a saturating dose of anti-IL7 mAb.

\section{Results}

Immunologic phenotype of PBMC. PBMC were isolated from blood samples of patients, by centrifugation over Ficoll gradient. Lymphocytosis of patients ranged from 6,000 to 80,000 / $\mathrm{mm}^{3}$, and Sézary cells, as atypical lymphocytes with cerebriform convoluted nuclei, determined by morphological examination, represent $15-85 \%$ of total patients' lymphocytes. As shown in Table I, $\mathrm{CD}^{+}$cells ranged from 44 to $97 \%$, (in large excess over $\mathrm{CD} 8{ }^{+}$cells) in all the patients. $\mathrm{CD} 7$ is a pan-T cell marker expressed on $>90 \%$ of $\mathrm{CD}^{+}$cells of normal PBMC (7). In our series, the percentage of atypical lymphocytes almost correlated with a low number of $\mathrm{CD} 7^{+}$cells: as shown, all the patients with at least $60 \%$ of atypical lymphocytes have $15 \%$

Table I. Phenotypic Analysis of Sézary PBMC

\begin{tabular}{|c|c|c|c|c|c|c|c|c|c|c|c|c|}
\hline $\begin{array}{l}\text { Patients } \\
\text { (stage) }\end{array}$ & $\begin{array}{l}\text { Atypical } \\
\text { lymph } \\
(\%)\end{array}$ & $\mathrm{CD} 2$ & CD3 & CD4 & CD7 & CD8 & CD14 & CD19 & CD25 & CD56 & CD71 & DR \\
\hline BEL (IVA) & 85 & 87 & 90 & 92 & 3 & 1 & 2 & 2 & 3 & 3 & 3 & 2 \\
\hline BIL (IVA) & 20 & 31 & 88 & 84 & 59 & 8 & 1 & 3 & 6 & 2 & ND & 10 \\
\hline BOS (III) & 25 & 62 & 59 & 56 & 36 & 10 & 18 & 15 & 13 & 5 & 29 & 31 \\
\hline CHA (IVA) & 60 & 96 & 95 & 93 & 7 & 3 & 2 & 1 & 38 & ND & ND & 7 \\
\hline CLA (IVA) & 20 & 69 & 68 & 66 & 48 & 12 & ND & 8 & ND & 3 & ND & 10 \\
\hline DEB (IVA) & 80 & 90 & 95 & 97 & 6 & 6 & 8 & 7 & 14 & 7 & 43 & 46 \\
\hline GEO (III) & 60 & 83 & 87 & 81 & 15 & 6 & 6 & 4 & 5 & ND & ND & 11 \\
\hline LAC (III) & 62 & 83 & 87 & 81 & 15 & 10 & 4 & 6 & 34 & 6 & 7 & 11 \\
\hline LAV (IVB) & 15 & 83 & 69 & 69 & 60 & 15 & 5 & 6 & 6 & 6 & 7 & 10 \\
\hline RIC (III) & 40 & 90 & 93 & 87 & 94 & 5 & 2 & 4 & 3 & 4 & 2 & 5 \\
\hline TET (IVA) & 30 & 71 & 69 & 69 & 24 & 16 & 12 & 4 & 8 & ND & ND & 7 \\
\hline ZIC (III) & ND & 78 & 75 & 75 & 68 & 9 & 13 & 5 & 4 & 4 & 16 & 3 \\
\hline
\end{tabular}

Stages are indicated according to national cutaneous T-cell lymphoma workshop staging classification. Atypical lymph percent Sézary cells based on morphological examination on May Grünwald Giemsa staining. Results are expressed as percentage of positive viable cells. ND, not done. 
or less of $\mathrm{CD}^{+}$cells. With the exception of patient RIC, double staining experiments confirmed the existence of a significant proportion of $\mathrm{CD}^{-}$cells among the $\mathrm{CD} 4$ population (data not shown). These data indicate the existence in a majority of patients, of a subpopulation of cells expressing a helper $\mathrm{T}$ cell phenotype, $\mathrm{CD}^{+} \mathrm{CD}^{+}{ }^{+} \mathrm{CD} 7^{-}$, which is a classical feature of Sézary lymphoma cells (4-8). Also, as reported by others, these blood cells do not seem to express activation markers: for a majority of patients CD25, HLA-DR, and CD71 (transferrin receptor) showed minimal expression. Other lineage markers for B cells (CD19), monocytes (CD14), and natural killer cells (CD56) showed normal expression.

Proliferative responses of $P B M C$. The proliferative responses of PBMC were compared, using a $\mathrm{T}$ cell mitogen (PHA) and various cytokines (Table II). As shown, PBMC from the 12 Sézary patients were only weakly proliferating on day 3 to PHA and the level of mitogenic response does not correlate with the disease stage nor the proportion of Sézary cells in the blood. Although PHA induced T cell proliferation is mainly considered as IL2 dependent, direct IL2 response of patients' PBMC was absent or weak (two- to threefold increase). One exception is patient $\mathrm{CHA}$, who had $38 \%$ of $\mathrm{CD} 25^{+}$lymphoid cells and responded to recombinant IL2 with a proliferative index of 9. Other cytokines, IL1 $\beta$, IL3, and IL4, did not induce any significant proliferation on a 3-d assay. In contrast, recombinant IL 7 could generate in all patients a very substantial (3- to 40-fold increase) proliferative response.

When compared to normal T cells, the IL7 response peaked on days 2-3 on Sézary PBMC, while normal cells showed maximal proliferation on days 6-7. Based on these data, IL7 is the best cytokine we tested capable to induce Sézary cell proliferation.

Establishment of IL7 dependent lymphoma cell lines. Next, we tried to test the capacity of IL7 to maintain in long term culture human Sézary cells. For this, PBMC from eight patients were cultured with supernatant of a human IL7-producing mouse stromal cell line (M210B4-hIL7). This line, in which the human IL7 gene has been introduced by retroviral gene transfert (provided by Dean J. Thacker), produced on a regular basis $40-60 \mathrm{ng} / \mathrm{ml}$ of hIL 7 in the supernatant. Cultures were maintained as described in Methods. Fig. $1 A$ show the establishment and growth characteristics of a cell line from patient RIC on the initial 10 wk of culture. In IL7 containing medium, a slow but regular growth is observed, with a doubling time of about $10 \mathrm{~d}$. When the culture is switched to medium containing supernatant from control stromal line (M210B4.Neo) containing the retroviral vector only, the cells stopped to multiply and eventually died within $4-5$ wk. Fig. $1 B$ confirmed on established culture the IL7 dependency. Proliferation was measured by $\left[{ }^{3} \mathrm{H}\right]$ thymidine incorporation on aliquots of cultures maintained on IL7 containing medium or mock supernatant. As shown on two cell lines, while proliferation was sustained in the continuous presence of IL7, depletion of this cytokine induces a dramatic decrease of the proliferation rate of these cell.

To further confirm that IL7 was the only growth factor involved in the proliferative capacity of the M210B4-IL7 supernatant, blockade experiments with anti-IL7 MAb were performed (Fig. 2). Results confirm the absence of activity in mock supernatant (M210B4-Neo), while proliferation induced by M210B4-hIL7 could be inhibited in a dose-dependent manner by mAb; complete blockage was achieved by $2 \mu \mathrm{g}$ of anti-IL7 mAb.

These results demonstrate that long term culture from peripheral blood of Sézary patients can be established and maintained with IL7. On the eight patients (BEL, BIL, BOS, CHA, CLA, LAV, RIC, and ZIC), we tried to derive cell lines, although all responded initially to IL7 and could be cultured for 2-10 wk, three lines (CHA, BEL, and RIC) could be successfully established. One (LAV) was lost by spontaneous EBV-B cell overgrowth.

Phenotypic analysis of Sézary lines. As previously mentioned from phenotypic analysis of patients' PBMC, loss of CD7 expression broadly correlated with the percentage of atypical lymphocytes. Therefore, we compared the time course expression of CD4 and CD7 markers during the first $10 \mathrm{wk}$ of cell culture in IL7. As shown in Fig. 3, starting from 60 to $88 \%$ of $\mathrm{CD}^{+}$cells in the four patients used in these experiments (BEL, CHA, RIC, and CLA) showed an increased CD4 expression over time. More importantly, during the same period,

Table II. Proliferative Response to Cytokines of Sézary PBMC

\begin{tabular}{|c|c|c|c|c|c|c|c|}
\hline \multirow[b]{2}{*}{ Patients } & \multicolumn{7}{|c|}{ Culture conditions } \\
\hline & Medium & PHA-M & IL $1 \beta$ & IL2 & IL3 & IL4 & IL7 \\
\hline BEL & $487 \pm 142$ & $2,046 \pm 521$ & $231 \pm 29$ & $1,440 \pm 33$ & $302 \pm 91$ & $382 \pm 27$ & $7,918 \pm 449$ \\
\hline BIL & $724 \pm 68$ & $1,398 \pm 826$ & $732 \pm 79$ & $646 \pm 67$ & $731 \pm 34$ & ND & $14,618 \pm 878$ \\
\hline BOS & $450 \pm 43$ & $396 \pm 11$ & $445 \pm 14$ & $988 \pm 116$ & $257 \pm 72$ & $554 \pm 103$ & $2,780 \pm 410$ \\
\hline CHA & $623 \pm 86$ & $4,520 \pm 190$ & $700 \pm 46$ & $5,444 \pm 437$ & $812 \pm 251$ & $630 \pm 91$ & $4,514 \pm 451$ \\
\hline CLA & $420 \pm 23$ & $6,200 \pm 116$ & $201 \pm 63$ & $2,077 \pm 34$ & $203 \pm 41$ & $388 \pm 63$ & $18,670 \pm 1,362$ \\
\hline DEB & $1,150 \pm 134$ & $2,811 \pm 128$ & $127 \pm 44$ & $3,271 \pm 47$ & $324 \pm 20$ & $1,410 \pm 129$ & $2,621 \pm 87$ \\
\hline GEO & $993 \pm 117$ & ND & ND & $981 \pm 38$ & ND & ND & $5,278 \pm 422$ \\
\hline LAC & $956 \pm 81$ & $2,250 \pm 531$ & $117 \pm 59$ & $1,180 \pm 162$ & $1,171 \pm 20$ & $1,413 \pm 102$ & $14,810 \pm 905$ \\
\hline LAV & $628 \pm 30$ & $2,964 \pm 55$ & $112 \pm 61$ & $1,225 \pm 49$ & $1,052 \pm 46$ & $820 \pm 63$ & $10,170 \pm 823$ \\
\hline RIC & $432 \pm 112$ & $3,836 \pm 409$ & $121 \pm 14$ & $168 \pm 204$ & $206 \pm 127$ & $987 \pm 28$ & $2,806 \pm 164$ \\
\hline TET & $119 \pm 126$ & $715 \pm 12$ & $61 \pm 28$ & $170 \pm 28$ & ND & ND & $2,903 \pm 530$ \\
\hline $\mathrm{ZIC}$ & $700 \pm 142$ & $3,035 \pm 344$ & $388 \pm 71$ & $1,728 \pm 43$ & ND & ND & $11,212 \pm 402$ \\
\hline
\end{tabular}

Results are expressed as cpm tritiated thymidine incorporated by $10^{5}$ cells during the last $18 \mathrm{~h}$ of a 3-d culture. ND, not done. 


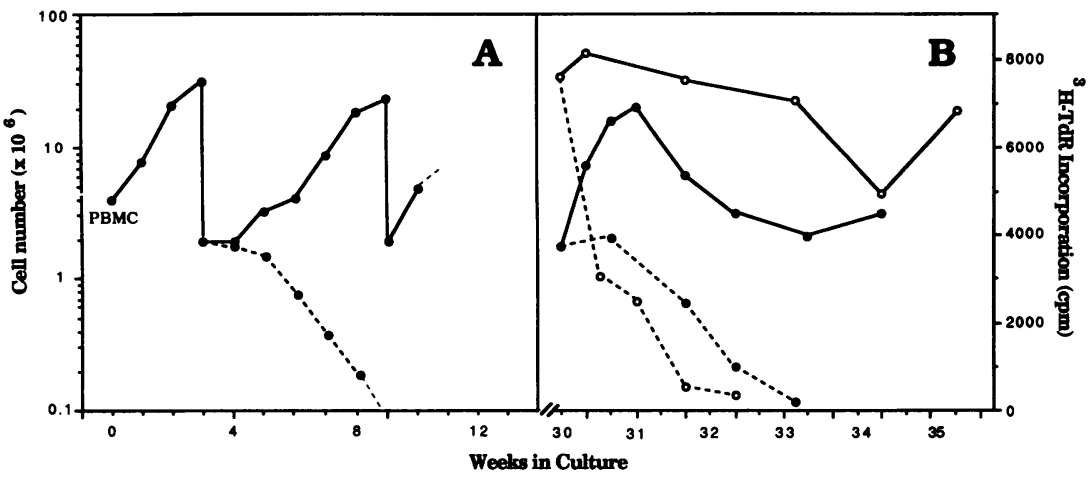

Figure 1. Establishment and IL7 growth dependency of cultured Sézary cells. $(A)$ Growth of patient RIC's PBMC with IL7 20\% M210B4-hIL7 containing medium (plain line) and mock supernatant (dashed line). ( $B$ ) Proliferation of long time cultured lines from patients RIC (closed circles) and CHA (open circles) with (plain line) and without (dashed line) IL7 containing medium.
CD7 expressing cells were rapidly lost and became virtually undetectable after $4 \mathrm{wk}$, except for patient RIC, who remained $\mathrm{CD}^{+}$, this phenotype being stable in long term culture. Another patient (BEL), from whom a line was successfully derived, was not informative in these experiments since PBMC already contained more than $90 \%$ of $\mathrm{CD}^{+} \mathrm{CD}^{-}$cells.

Immunofluorescence analysis of long term culture cells showed an homogenous phenotype of nonactivated resting helper $\mathrm{T}$ cells, $\mathrm{CD}_{2}{ }^{+} \mathrm{CD}_{3}{ }^{+} \mathrm{CD}_{4}{ }^{+}, \mathrm{Tac}^{-}$, and $\mathrm{HLA}-\mathrm{DR}{ }^{-}$, other non- $T$ cell lineage markers are negative (not shown). Cytologic examination of May-Grünwald Giemsa staining of the three established cell lines confirmed phenotypic homogeneity, cells presenting as lymphocytes with circonvoluted cerebriform nuclei and frequent binucleated cells, characteristic of Sézary lymphoma cells (not shown).

Analysis of TCR $\beta$ gene rearrangement. To further confirm that cells expanded in IL7 were derived from the malignant clone present in the blood, analysis of TCR- $\beta$ gene rearrangement was performed. For each patient (BEL, CHA, and RIC), Southern blots were performed from fresh PBMC and cells from the established lines after DNA was cut with BamHI, EcoRI $(C \beta 1)$, or HindIII $(C \beta 2)$. For all three lines, an identical rearrangement was observed when compared with the peripheral blood cells, as shown on the blot autoradiographs of Fig. 4, demonstrating that malignant cells are present in each Sézary line.

Epidermal keratinocytes produce hIL7. Several reports suggested that skin, in contrast to the blood, is a preferential site of proliferating tumoral cells in vivo. Thus, epidermal cells

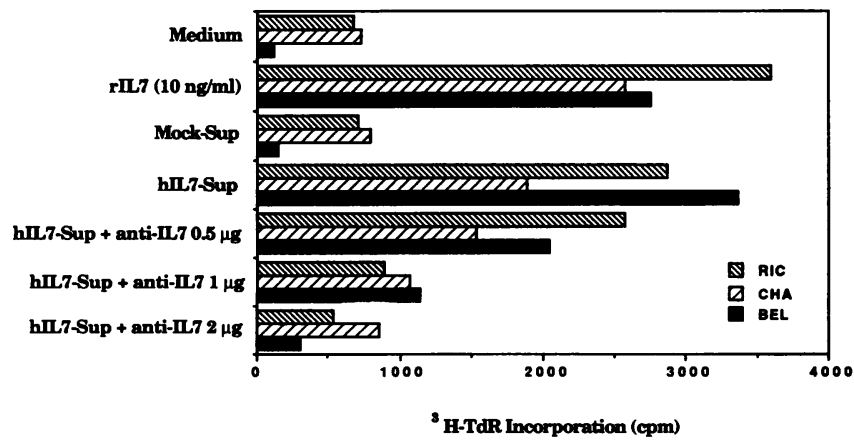

Figure 2. mAb anti IL7 inhibits the growth of Sézary line induced by M210B4-hIL7 supernatant. 50,000 cells from BEL, CHA, and RIC lines were cultured with medium and/or 20\% M210B4-hIL7 sup in the presence or absence of increasing dose of anti-IL7 MAb. On day 3 , cultures were pulsed with $1 \mu \mathrm{Ci}$ of ${ }^{3} \mathrm{H}-\mathrm{TdR}$ per well. should provide a suitable microenvironment for Sézary cells. Therefore, we tested the capacity of cultured epidermal keratinocytes from normal individuals to support the proliferation of our Sézary lines. As shown in Fig. 5, supernatants from these cells could induce a dose-dependent proliferative response of Sézary cells. In addition, this proliferation could be completely specifically blocked by a saturating dose of anti-IL $7 \mathrm{mAb}$, since a similar dose of isotype matched anti-IL3 mAb was ineffective. These data demonstrate the production of IL7 by unstimulated cultured cytokeratin ${ }^{+}$vimentin $^{-}$keratinocytes.

To better estimate the level of IL 7 production by keratinocytes, bioactivity of several supernatants was quantified in a mouse thymocyte proliferation assay. Table III summarizes the results obtained. As expected, M210B4-Neo supernatant was devoid of any IL7 activity, whereas M210B4-hIL7 produced $\sim 40-60 \mathrm{ng} / \mathrm{ml}$ of hIL 7. The other control used, thymic epithelial cells cultured in the same conditions as keratinocytes, also showed high levels of IL7 production $(150 \mathrm{ng} / \mathrm{ml})$. In these conditions, IL7 activity contained in keratinocyte supernatants ranged between 15 and $60 \mathrm{ng} / \mathrm{ml}$, whereas Sézary lines from patients CHA and RIC did not produce any activity. These data may suggest a possible in vivo paracrine growth of Sézary cells in the skin.

\section{Discussion}

Sézary syndrome is a form of cutaneous $\mathrm{T}$ cell proliferative disorder characterized by generalized erythroderma accompanied by abnormal lymphoid cells in the blood. The etiology of

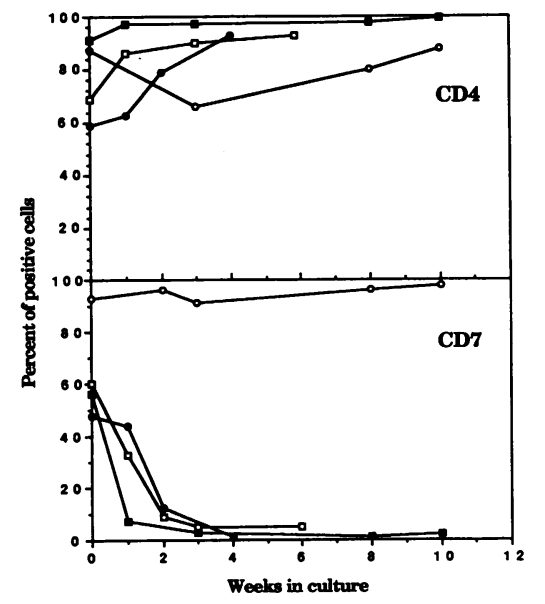

Figure 3. Time course evolution of $\mathrm{CD} 4$ and CD7 expression by Sézary PBMC culture in IL7 containing medium. PBMC of patients LAV, CHA, RIC, and CLA were cultured in 20\% M210B4-IL7 containing medium and the percentage of cells expressing CD4 and CD7 antigens were evaluated by FACS $^{\circledR}$ analysis at the indicated times of culture. - - , LAV; - - - CHA; - O -, RIC; - $\bullet-$, CLA. 


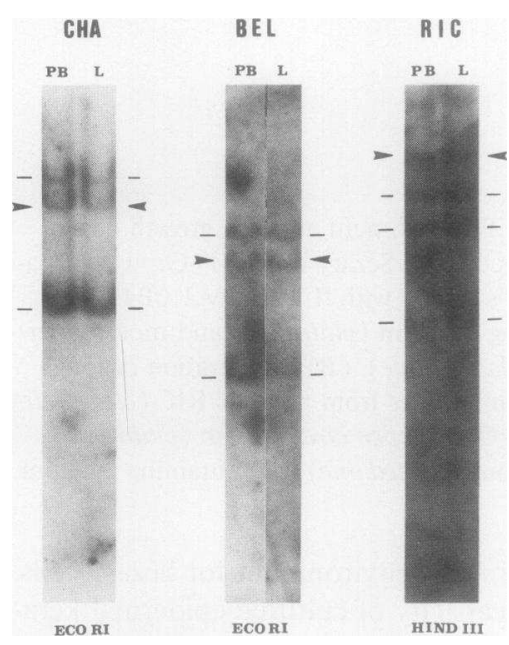

Figure 4. Analysis of TCR- $\beta$ gene rearrangements demonstrating clonal origin of Sézary lines. DNA from peripheral blood $(P B)$ and line $(L)$ from patient BEL, CHA, and RIC cells were digested with either EcoRI or HindIII to detect $C \beta 1$ or $C \beta 2$ gene rearrangements by Southern blot hybridization. Bars, germ line positions; arrows, rearranged bands. the disease has remained unclear, studies being hampered by the lack of in vitro model. While T cells proliferating in the skin are difficult to access, circulating lymphocytes are usually refractory to $T$ cell mitogen stimulations (9-11). Despite occasional response of some patients to IL2 this insensitivity to stimulation explain that establishment of Sézary cell lines have generally been unsuccessful (12-14). IL7, initially described as a pre-B cell growth factor, is a cytokine produced by mesenchymal cells, which can also sustain the proliferation of thymocytes and human peripheral blood $T$ cells $(15,16)$. Here we demonstrate that IL7 is a potent growth factor on peripheral blood Sézary cells, and can be used to generate in vitro stable IL7-dependent malignant cell lines.

We studied a series of 12 Sézary patients with advanced disease and 15-85\% atypical Sézary cells in the blood. As reported, immunofluorescence studies of patients' PBMC suggest a classical $\mathrm{CD}^{+}{ }^{+}$resting helper $\mathrm{T}$ cell phenotype for circulation lymphoma cells (3-6). Lack of Leu8 and CD7 expression on peripheral blood Sézary cells have been previously reported and proposed as a marker for circulating Sézary cells, allowing distinction of cutaneous $T$ cell lymphoma from acute $\mathrm{T}$ cell leukemias $\left(\mathrm{CD}^{+}\right)(7,8)$. In our study, lack of expres-

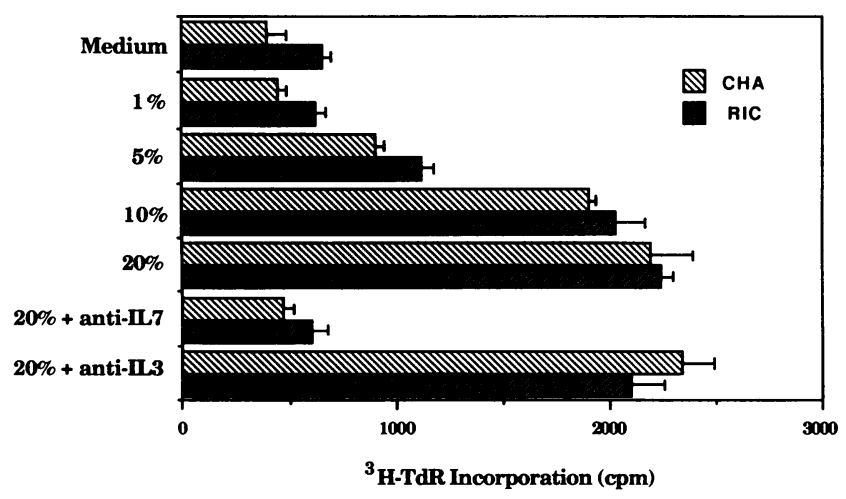

Figure 5. Proliferation of cultured Sézary cells to keratinocytes supernatants. 50,000 cells were cultured in $200 \mu \mathrm{l}$ of medium with or without increasing concentrations of cultured keratinocyte supernatant (see Methods), with and without $2 \mu \mathrm{g}$ of anti-IL7 of anti-IL3 MAbs. Proliferation was measured by thymidine incorporation on day 3 .
Table III. Human IL7 Production by Epithelial Cells

\begin{tabular}{lc}
\multicolumn{1}{c}{ Cell type } & hIL7 \\
& $n g / m l$ \\
& \\
M210B4-Neo & Not detectable \\
M210B4-hIL7 & $40-60$ \\
Human keratinocytes & $15-60$ \\
Thymic epithelial cells & 150 \\
Sézary line CHA & Not detectable \\
Sézary line RIC & Not detectable
\end{tabular}

BALB/c thymocytes were cultured at $10^{6}$ cells per well in $0.2 \mathrm{ml}$ of RPMI 1640 medium supplemented with $10 \%$ FCS, $5 \times 10^{-5} \mathrm{M}$ 2-mercaptoethanol, $200 \mu \mathrm{g} / \mathrm{ml}$ glutamine, and containing serial dilutions of the supernatant to be assayed or known concentrations of purified recombinant human IL7. After $3 \mathrm{~d}$, cultures were pulsed with $1 \mu \mathrm{Ci}$ per well ${ }^{3} \mathrm{H}-\mathrm{TdR}$ and harvested $6 \mathrm{~h}$ later for counting.

sion of $\mathrm{CD}^{+}{ }^{+} \mathrm{CD}^{-}$phenotype correlated quite well with the percentage of atypical lymphocytes in the blood. We also observed a progressive loss of CD7-expressing cells during the initial period of establishment of our Sézary cell lines. However, in one patient initially expressing a high percentage of $\mathrm{CD} 4{ }^{+} \mathrm{CD}^{+} \mathrm{PBMC}$, a maintenance of this phenotype was noted in the malignant cell line. Despite this exception, we believe that a $\mathrm{CD}^{-}$phenotype, associated with a large excess of CD4 to CD8 expression, is a good marker for cutaneous T cell lymphoma. In addition, our ability to maintain $\mathrm{CD} 7^{+} \mathrm{RIC}$ Sézary cells in long term culture militates against a possible modulation of CD7 antigen expression or a preferential growth of $\mathrm{CD}^{-}$normal $\mathrm{T}$ cells, because of the culture conditions we used.

Refractoriness of Sézary cells to respond to T cell stimuli is a common observation. One possible explanation is the need for an activation signal and / or a particular cytokine (s) requirement for Sézary cell proliferation. This is illustrated by the fact that, although circulating malignant cells are usually resting, skin-infiltrating $T$ cells from mycosis fungoides/Sézary syndrome patients have an activated phenotype, expressing Tac and HLA-DR, and are in active cell cycling (8). Proliferative response to IL2 can sometimes be observed, but as in our study, most of the patients PBMC failed to respond or responded poorly to this cytokine. Preactivation usually increases or induces IL2 responsiveness (14). However, physiological relevance for IL2 induced proliferation in the skin is unclear because Sézary cells usually failed to produce sufficient amount of IL2 to support their own proliferation, and other sources in the skin are not obvious (24). In this context, our observation that recombinant IL7 could directly induce the proliferation of PBMC from all the patients we tested is of importance. We also observed that this proliferation is not blocked by Cyclosporin A, confirming that IL7-induced response is not IL2-mediated. In addition, while proliferation of Sézary PBMC response to IL7 reached a plateau on days 3-4, that of normal $T$ cells needed 6-7 d $(25,26)$. This kinetic suggests that the proliferative cells responding to IL7 belonged primarily to the malignant compartment.

This strong proliferation to IL7 allowed us to test the possibility to maintain in long term lymphoma cells. Eight patients were evaluated, all grew well for at least $2-6 \mathrm{wk}$; three could be 
established as IL7-dependent cell line. A fourth one was lost at week 6 by EBV B cell overgrowth. Reasons for failure to maintain other lines for longer period is unclear, however, IL7 have been reported to induce cytotoxic $\mathrm{T}$ cell generation (27-29). Cell lines were maintained in medium containing supernatant from a mouse stromal cell line containing the human IL7 gene by retroviral-mediated gene transfer (M210B4-hIL7). IL7 dependency was demonstrated by progressive death of cells after switching to medium containing supernatant from control cell line (M210B4-Neo). The implication of HTLV-I as a potential etiologic agent for mycosis fungoides/Sézary syndrome has been suggested, although contradictory reports exist in the literature $(30,31)$. Although our patients were serologically negative for HTLV-I (data not shown), we haven't tested the absence of viral sequences in the lymphocytes, however, exogenous IL 7 dependency of our cells indicates that if HTLV-I is by any way necessary, it is not sufficient for cell line maintenance.

The cells grow slowly in culture, with a mean doubling time of $10 \mathrm{~d}$, which is consistent with the relatively indolent nature of this disorder. Importantly, beside the homogeneity of the phenotype, cell line presented the typical morphology of Sézary cells on May Grünwald-Giemsa staining with a convoluted cerebriform nuclei. Furthermore, analysis of TCR- $\beta$ chain gene rearrangement demonstrate that for three lines, an identical rearranged band is evidenced when comparing the blood and cultured Sézary cells. This ascertains that the lines are relevant to the malignant clone. It also suggests that Sézary cells have a selective growth advantage for IL7 responsiveness. Of note, we failed to maintain in long term culture normal PBMC with IL7.

As mentioned above, Sézary cells are activated and proliferate in the skin of mycosis fungoides/Sézary syndrome and are associated with hyperkeratosis. This leads us to investigate the production of IL7 by cultured keratinocytes. We showed that indeed these cells produce a factor that could induce the proliferation of the lymphoma cells and that could be blocked by anti-IL7 $\mathrm{mAb}$. In addition, IL7 content could be measured in a bioassay and ranged between 15 and $60 \mathrm{ng} / \mathrm{ml}$, a dose comparable to those of the IL7-producing cell line we used to maintain our Sézary lines. This production is not limited to epidermal epithelial cells, since (as shown in Table III) thymic epithelial cells cultured in the same conditions as keratinocytes also produced IL7, as previously reported $(15,16)$.

Tumors arise as a result of multiple oncogeneic events on continuously cycling cells. Chronic stimulation and exacerbated cytokine-induced proliferation, augment the risk of transformation and certainly play an important role in tumor progression. This can be illustrated by the implication of IL6 and IL2 in the evolution of multiple myeloma and Waldenström macroglobulinemia, and of adult $\mathrm{T}$ cell leukemia, respectively (32-35). IL7 has also been presented as a proliferating factor for pre-B and $\mathrm{T}$ acute lymphoblastic leukemias $(36,37)$.

In conclusion, for the first time, we demonstrated that IL7 is a potent growth factor for Sézary cells, and may be an important paracrine cytokine in the physiopathology of cutaneous $\mathrm{T}$ cell lymphoma.

\section{Acknowledgments}

This work was supported by the Centre National de la Recherche Scientifique.

\section{References}

1. Brouet, J. -C., G. Flandrin, and M. Seligmann. 1973. Indications of the thymus-derived nature of the proliferating cells in six patients with Sézary's syndrome. N. Engl. J. Med. 289:341-344.

2. Edelson, R. L. 1980. Cutaneous T cell lymphoma: mycosis fungoides, Sézary syndrome, and other variants. J. Am. Acad. Dermatol. 2:89-106.

3. Willemze, R., W. A. van Vloten, J. Hermans, M. J. Damsteeg, and C. J. Meijer. 1983. Diagnostic criteria in Sézary syndrome: a multiparameter study of peripheral blood lymphocytes in 32 patients with erythroderma. J. Invest. Dermatol. 81:392-397.

4. Broder, S., R. L. Edelson, M. A. Lutzner, D. L. Nelson, R. P. MacDermott, M. E. Durm, C. K. Goldman, B. D. Meade, and T. A. Waldmann. 1976. The Sézary syndrome: a malignant proliferation of helper T cells. J. Clin. Invest. 58:1297-1304.

5. Boumsell, L., A. Bernard, E. L. Reinherz, L. M. Nadler, J. Ritz, H. Coppin, Y. Richard, L. Dubertret, F. Valensi, L. Degos, et al. 1981. Surface antigens on malignant Sézary and T-CLL cells correspond to those of mature T cells. Blood. 57:526-530.

6. Kung, P. C., L. C. Berger, G. Goldstein, P. Logerfo, and R. C. Edelsen. 1981. Cutaneous $T$ cell lymphomas: characterization by monoclonal antobodies. Blood. 57:261-267.

7. Haynes, B. F., R. S. Metzgar, J. D. Minna, and P. A. Bunn. 1981. Phenotypic characterization of cutaneous T-cell lymphoma. Use of monoclonal antobodies to compare with other malignant T cells. N. Engl. J. Med. 304:1319-1323.

8. Wood, G. S., S. R. Hong, D. T. Sasaki, E. A. Abel, R. T. Hoppe, R. A. Warnke, and V. B. Morhenn. 1990. Leu-8/CD7 antigen expression by CD3 ${ }^{+} \mathrm{T}$ cells: comparative analysis of skin and blood in mycosis fungoides/Sézary syndrome relative to normal blood values. J. Am. Acad. Dermatol. 22:602-607.

9. Romagnani, S., G. F. Del Prete, E. Maggi, A. Cadoni, G. Corte, S. Moretti, and M. Ricci. 1982. Phenotypic and functional characterization of a Sézary cell. J. Clin. Immunol. 2:343-349.

10. Gazdar, A. F., D. N. Carney, P. A. Bunn, E. K. Russell, E. S. Jaffe, G. P. Schechter, and J. G. Guccion. 1980. Mitogen requirement for the in vitro propagation of cutaneous T-cell lymphomas. Blood. 55:409-415.

11. Carney, D. N., P. A. Bunn, G. P. Schechter, and A. F. Gazdar. 1980. Mitogen responses and flow microfluorometry of circulating cells in the Sézary syndrome. Int. J. Cancer. 26:535-541.

12. Poiesz, B. J., F. W. Ruscetti, J. W. Mier, A. M. Woods, and R. C. Gallo. 1980. T-cell lines established from T-lymphocytic neoplasia by direct response to T-cell growth factor. Proc. Natl. Acad. Sci. USA. 77:6815-6819.

13. Golstein, M. M., C. Farnarier-Siedel, P. Daubney, and S. Kaplanski. 1986. An OKT4 ${ }^{+}$T-cell population in Sézary syndrome: attempts to elucidate its lack of proliferative capacity and its suppressive effect. Scand. J. Immunol. 23:53-64.

14. Abrams, J. T., S. R. Lessin, S. K. Ghosh, P. C. Nowell, W. Ju, E. C. Vonderheid, A. H. Rook, and E. DeFreitas. 1991. Malignant and nonmalignant T cell lines from human lymphotropic virus type I-negative patients with Sézary syndrome. J. Immunol. 146:1455-1462.

15. Henney, C. S. 1989. Interleukin 7: effects on early events in lymphopoiesis. Immunol. Today. 10:170-173.

16. Goodwin, R. G., S. Lupton, A. Schmierer, K. J. Hjerrild, R. Jerzy, W Clevenger, S. Gillis, D. Cosman, and A. Namen. 1989. Human interleukin 7: molecular cloning and growth factor activity on human and murine B-lineage cells. Proc. Natl. Acad. Sci. USA. 86:302-306.

17. Bunn, P. A., R. Edelson, S. S. Ford, S. and E. Shackney. 1981. Patterns of cell proliferation and cell migration in the Sézary syndrome. Blood. 57:452-463.

18. Schwarmeier, J. D., E. Paietta, T. Radaszkiewicz, K. Konrad, and L. Marosi. 1981. Proliferation kenetics of Sézary cells. Blood. 57:1049-1054.

19. Rheiwald, J. G., and H. Green. 1975. Serial cultivation of strains of a human epidermal keratinocytes: the formation of keratinizing colonies from single cells. Cell. 6:331-344.

20. Dalloul, A. H., M. Arock, C. Fourcade, A. Hatzfeld, J.-M. Bertho, P. Debré, and M. D. Mossalayi. 1991. Human thymic epithelial cells produce Interleukin-3. Blood. 77:69-74.

21. Wigler, M., R. Sweet, G. K. Sim, B. Wold, A. Pellicer, E. Lacy, T. Maniatis, S. Siverstein, and R. Axel. 1979. Transformation of mammalian cells with genes from procaryotes and eucaryotes. Cell. 16:777-785.

22. Yoshikai, Y., D. Anateniore, S. P. Clark, Y. Yanagi, R. Sangster, P. Van de Elser, C. Terhorst, and T. W. Mak. 1984. Sequence and expression of transcripts of the human T cell receptor $\beta$ chain genes. Nature (Lond.). 111:11081121.

23. Colon, P. J., P. J. Morrissey, R. P. Nordan, K. H. Grabstein, K. S. Prickett, S. G. Reed, R. Goodwin, D. Cosman, and A. E. Namen. 1989. Murine thymocytes proliferate in direct response to Interleukin-7. Blood. 74:1368-1373.

24. Solbach, W., C. E. Lange, M. Rollinghoff, and H. Wagner. 1984. Growth, interleukin-2 production, and responsiveness to IL-2 in T4-positive T lymphocyte populations from malignant cutaneous $T$ cell lymphoma (Sézary's syndrome): the effect of cyclosporin A. Blood. 64:1022-1027.

25. Welch, P. A., A. E. Namen, R. G. Goodwin, R. Armitage, and M. D. 
Cooper. 1989. Human IL-7: a novel T cell growth factor. J. Immunol. 143:35623567.

26. Londei, M., A. Verhoef, C. Hawrylowicz, J. Groves, P. De Berardinis, and M. Feldmann. 1990. Interleukin 7 is a growth factor for mature human T cells. Eur. J. Immunol. 20:425-428.

27. Anderson, M. R., H. M. Sassenfeld, and M. B. Widmer. 1990. Interleukin 7 enhances cytolytic $T$ lymphocyte generation and induces lymphokine-activated killer cells from human peripheral blood. J. Exp. Med. 172:577-587.

28. Hickman, C. J., J. A. Crim, H. S. Motowski, and J. P. Siegel. 1990. Regulation of human cytotoxic T lymphocyte development by IL-7. J. Immunol. 145:2415-2420.

29. Stotter, H., M. C. Custer, E. S. Bolton, and M. T. Lotze. 1991. IL-7 induces human lymphokine-activated killer cell activity and is regulated by IL-4. J. Immunol. 146:150-155.

30. Capesius, C., F. Saal, E. Maero, A. Bazarbachi, J. Lasneret, L. Laroche, A. Gessain, F. Hojman, and J. Peries. 1991. No evidence for HTLV-I infection in 24 cases of French and Portuguese mycosys fungoides and Sézary syndrome (as seen in France). Leukemia (Basingstoke). 5:416-419.

31. Hall, W. W. C. R. Liu, O. Schneewind, H. Takahashi, M. K. Kaplan, G. Röupe, and A. Vahlne. 1991. Deleted HTLV-I provirus in blood and cutaneous lesions of patients with mycosis fungoides. Science (Wash. DC). 253:317-320.

32. Kawano, M., T. Hirano, T. Matsuda, T. Taga, Y. Horii, K. Iwato, H.
Asaoku, B. Tang, O. Tanabe, H. Tanaka, A. Kuramoto, and T. Kishimoto. 1988. Autocrine generation and requirement of BSF-2/IL6 for human multiple myeloma. Nature (Lond.). 332:83-85.

33. Levy, Y., J.-P. Fermand, S. Navarro, C. Schmitt, W. Vainchenker, M. Seligmann, and J.-C. Brouet. 1990. Interleukin 6 dependence of spontaneous in vitro differentiation of B cells from patients with IgM gammapathy. Proc. Natl. Acad. Sci. USA. 87:3309-3313.

34. Yodoi, J., and T. Uchiyama. 1986. IL2-receptor dysfunction and adult T cell leukemia. Immunol. Rev. 92:135-156.

35. Waldmann, T. A., D. L. Longo, W. J. Leonard, J. M. Depper, C. B. Tompson, M. Krönke, C. K. Goldman, S. Sharrow, K. Bongiovanni, and W. C. Green. 1985. Interleukin 2 receptor expression in HTLV-I associated adult T cell leukemia. Cancer Res. Suppl. 45:4559-4562.

36. Touw, I., K. Pouwels, T. Van Agthoven, R. van Gurp, L. Budel, H. Hoogerbrugge, R. Delwel, R. Goodwin, A. Namen, and B. Lowenberg. 1990. Interleukin-7 is a growth factor of precursor $B$ and $T$ acute lymphoblastic leukemia. Blood. 75:2097-2101.

37. Dibirdik, I., L. Mridula-Chandan, J. A. Ledbetter, L. Tuel-Ahlgren, $O$. Vedat, K. G. Waddick, K. Gajl, G. L. Schieven, and F. Uckun. 1991. Engagement of IL7 receptor stimulates tyrosine phosphorylation, PI turover and clonal proliferation of a human T lineage acute lymphoblastic leukemia cells. Blood. 78:564570. 